\title{
Relationship between platelet-to-lymphocyte ratio and cardiac syndrome $x$
}

\section{Platelet/lenfosit oranı ille kardliyak sendrom $\mathrm{x}$ arasındaki ilişki}

\author{
Hasan Ata Bolayir
}

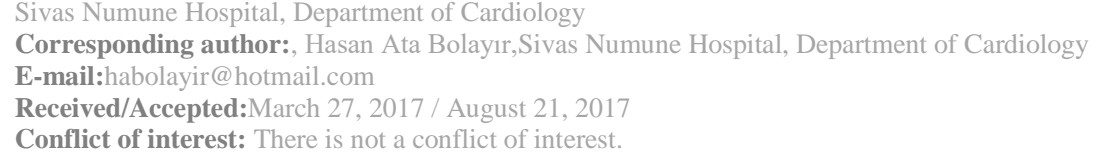

\section{SUMMARY}

Objective:Cardiac syndrome $\mathrm{X}$ consist of anginal-like typical chest pain with positive cardiovascular stres test or presence of ischemia on myocardial perfusion scintigraphy but no flow-limiting stenosis on coronary angiography. The more likely pathophysiologic mechanisms for patients with cardiac syndrome $\mathrm{X}$ are subsequent microvascular ischemia, endothelial dysfunction and inflammation which may be the explanation of their anginal-like chest pain. Platelet to lymphocyte ratio is a potential biomarker for inflammation, and associated with endothelial dysfunction. We aimed to compare the role of platelet to lymphocyte ratio in patients with cardiac syndrome X and control subjects in this study. Method:The study group consist of 100 patients who underwent coronary angiography and were diagnosed as cardiac syndrome $\mathrm{X}$ according to the presence of exercise-induced typical angina pectoris and ischemia on myocardial perfusion scintigraphy with angiographically normal coronary arteries. For control subjects, we recruited 100 healthy gender- and age-matched individuals who were seen for health check-ups.

Results:According to comparison of the hematological indices, mean value of the platelet to lymphocyte ratio in study population was higher than control group ( $260 \pm 16$ vs $217 \pm 14$, respectively; $p=0.04$ )whereas the other hematological parameters did not differ between groups significantly.

Conclusions: The platelet to lymphocyte ratio, which is easily calculated from routinely studied compete blood count and therefore requires no additional cost might be usefull for the evaluation of cardiac syndrome $\mathrm{X}$ based on the results of our study.

Keywords: Cardiac syndrome X, platelet to lymphocyte ratio, inflammation

\section{ÖZET}

Amaç:Kardiyak sendrom X; koroner anjiyografide akım sınırlayıcı darlık olmaksızın, pozitif kardiyovasküler stres testin ya da miyokardiyal perfüzyon sintigrafisinde iskeminin eşlik ettiği anjina benzeri tipik gögüs ağrısından oluşur. Kardiyak sendrom X'li hastalardaki anjina benzeri göğüs ağrısını açıklayabilecek en muhtemel patofizyolojik mekanizmalar, takip eden mikrovasküler iskemi, endotelyal disfonksiyon ve inflamasyondur. Biz bu çalıșmada kardiyak sendrom X'li hastalardaki platelet/lenfosit oranını kontrollerle kıyaslayarak, platelet/lenfosit oranının bu hastalıktaki rolünü ortaya koymayı hedefledik.

Yöntem: Çalışma grubu anjiyografik olarak normal koroner arterleri olan ancak egzersizle tetiklenen tipik anjina pektorise ya da miyokardiyal perfüzyon sintigrafisinde iskemiye sahip olduğu için kardiyak sendrom X tanısı almış, koroner anjiyografi uygulanmış 100 hastadan oluşmaktadır. Kontrol grubu içinse sağlık kontrolleri için başvurmuş hasta grubuna benzer yaş ve cinsiyete sahip sağlıklı 100 gönüllü alındı.

Bulgular: Hematolojik belirteçler karşılaştırıldığında, çalışma grubundaki ortalama platelet/lenfosit oranları kontrol

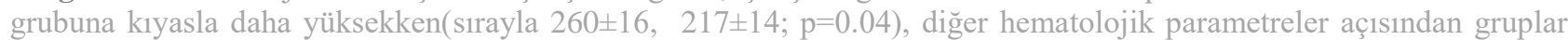
arasinda anlamlı fark yoktu.

Sonuç: Çalışmamızın sonuçlarına dayanarak, rutin olarak çalışılan tam kan sayımından kolayca hesaplanabilen ve bu nedenle ek masraf gerektirmeyen platelet/lenfosit oranının kardiyak sendrom X'in değerlendirilmesinde kullanışlı olabileceği söylenebilir.

Anahtar sözcükler: Kardiyak sendrom X, platelet/lenfosit oranı, inflamasyon 


\section{INTRODUCTION}

Chest pain is a common symptom, accounting for more than 5 million emergency department visits in each year ${ }^{1}$. A great number of these patients have cardiac syndrome X (CSX). CSX consist of anginal-like typical chest pain with positive cardiovascular stres test or presence of ischemia on myocardial perfusion scintigraphy but no flowlimiting stenosis on coronary angiography ${ }^{2}$. The more likely pathophysiologic mechanisms for patients with CSX are subsequent microvascular ischemia and endothelial dysfunction, which may be the explanation of their anginal-like chest pain ${ }^{3}$. The correlation between endothelial dysfunction and the platelet to lymphocyte ratio (PLR), which has been recently accepted as a potential biomarker for inflammation, has been showned in previous studies. However, we have not encountered any study about the role of the PLR in patients with CSX in the literature. Accordingly, we aimed to compare the role of PLRs in patients with CSX and control subjects in this study.

\section{MATERIAL AND METHODS}

\section{Patient Characteristics}

The study group consist of 100 patients who underwent coronary angiography on an outpatient basis at the cardiology department of Sivas Numune Hospital between October 2014December 2015 and were diagnosed as CSX according to the presence of exercise-induced typical angina pectoris and ischemia on myocardial perfusion scintigraphy with angiographically normal coronary arteries. One hundered consecutive age- and gender-matched people with no anginal chest pain and negative cardiovascular stress test were enrolled the control group. Patients who had unstable chest pain, previous myocardial infarction, coronary vasospasm, any coronary artery atherosclerotic lesions (including plaques and ectasia), moderate to severe valvular heart disease, renal dysfunction (serum creatinine $>1.5$ $\mathrm{mg} / \mathrm{dl}$ for men and $>1.4 \mathrm{mg} / \mathrm{dl}$ for women), hepatic insufficiency(liver function tests greater than twice the upper limit of the laboratory reference range), left ventricular systolic dysfunction by echocardiography (ejection fraction $<0.40$ ), malignancies, hematological disorders, acute or chronic infectious or inflammatory diseases or steroid therapy were excluded from the study.

For the diagnosis of hypertension should be systolic blood pressure of $>140 \mathrm{~mm} \mathrm{Hg}$ or diastolic blood pressure of $>90 \mathrm{~mm} \mathrm{Hg}$ or the current use of antihypertensive drugs ${ }^{3}$.
Diabetes mellitus was defined as the use of antidiabetic medication or a fasting blood glucose of $\geq 126 \mathrm{mg} / \mathrm{dl}$. Smoking was described as the regular use of tobacco.

\section{Myocardial perfusion scintigraphy(MPS)}

One rest day and exercise or dipyridamole stress Tc-99m MIBI protocol were applied on MPS taken patients according to the recommendations of the Turkey Nuclear Association Working Group. At least 4 hours fasting was supplied before the stress study. If there were no medical contraindications, for diagnostic studies calcium channel blocker or beta -blocker medications, which can affect the heart rate and blood pressure in response to exercise, were discontinued before 48 hours. 8-10 $\mathrm{mCi}$ dose and 22 to $25 \mathrm{mCi}$ dose of Tc- $99 \mathrm{~m}$ sestamibi were injected intravenously to the patients respectively in stress and resting imaging. Exercise test was performed according to the modified Bruce protocol. Target heart rate ( 220 age ) x 0.85 was determined. When one of feeling faint, dyspnea, chest pain, syncope, atrial tachycardia or fibrillation, ventricular tachycardia, ST-segment elevation or $2 \mathrm{~mm}$ more than ST segment depression on monitor, second or third degree AV block development, systolic blood pressure drop ( baseline compared to $10 \mathrm{mmHg}$ and more falling) and measuring over $240 \mathrm{~mm} \mathrm{Hg}$ systolic or $120 \mathrm{~mm} \mathrm{Hg}$ diastolic blood pressure was seen on patient, the exercise test was terminated and was accepted as maximal effort was reached. When minimum $85 \%$ of maximum heart rate was reached, Tc- $99 \mathrm{~m}$ sestamibi was injected intravenously to the patients and effort test was continued for another one minute. After $0.14 \mathrm{mg} /$ $\mathrm{kg} / \min \mathrm{x} 4$ min dipyridamole intravenously injection to the patients, who were clinically unfit to exercise test with treadmill, Tc- $99 \mathrm{~m}$ sestamibi injection was made. 30 minutes after effort test / dipyridamole injection was finished, the patients were shooting. Nearly three hours later, Tc $99 \mathrm{~m}$ sestamibi which was 3 times dose of stress phase, were injected in the resting phase and imaging was performed after 45-60 minutes.

\section{Coronary Angiography}

Coronary angiograms were provideded via a femoral or radial catheter using the standard Judkins technique. Adenosine, nitroglycerin, or calcium channel blockers did not be used during the procedure. Two experienced angiographers who were unaware about the laboratory and exercise test data, reviewed the angiographic records. To exclude coronary artery spasm, a hyperventilation test was applied. The 
normality criteria of the coronary arteries was the absence of any luminal narrowing or irregularities.

\section{Laboratory Measurements}

After an overnight fasting, peripheral venous blood samples were drawn from patients. Total and differential leukocyte counts were measured by an automated hematology analyzer (Abbott Cell-Dyn 3700; Abbott Laboratory, Abbott Park, Illinois, USA). Absolute cell counts were used in the analyses. PLR was computed as platelet count divided by lymphocyte count. Total and highdensity lipoprotein cholesterol (HDL), triglycerides, and fasting plasma glucose levels were measured using the Abbott Architect C16000 auto-analyzer

(Architect C16000 auto-analyzer;

Abbott Laboratory, Abbott Park, Illinois, USA). Plasma low-density lipoprotein cholesterol (LDL) concentrations were calculated using the Friedewald equation.

\section{Statistical Analysis}

Data were analyzed using SPSS 20.0 statistical package program. Normality of the distribution of the continuous variables was evaluated using the Kolmogorov-Smirnov test and histograms.
Analyses of quantitative data were made with a Mann-Whitney U test, while analyses of qualitative data were made with a chi-square test or a Fischer test. Logistic regression analysis and chi-square test were used to determine the role of PLR in the development of CSX. Receiver operating characteristic curve (ROC) analysis was used for determining the optimum cut-off value of PLR for predicting CSX. Statistical significance level was accepted as $\mathrm{p}<0.05$.

\section{RESULTS}

Comparing the control group with the patient group in terms of baseline characteristics and laboratory parameters, no difference was determined for age, gender, presence of hypertension and diabetes mellitus, smoking, statin use, BMI (body mass index), lipid profiles, creatine/glucose/hemoglobin levels. Mean monocyte/neutrophil/white blood cell counts and mean value of NLR (neutrophil-tolymphocyte ratio) and MPV (mean platelet volume) were higher in the patient group and mean lymphocyte count was higher in control group, but these variables did not reach statical significance. Platelet count, CRP (C-reactive protein) level and mean PLR value were higher in patient group significantly $(\mathrm{p}=0,001 / \mathrm{p}=0,001 / \mathrm{p}=0,04)($ Table 1$)$.

Table-1. Comparison of baseline demographic, clinical, and laboratory characteristics of the control and the patient groups. Abbreviations: BMI: Body mass index, CRP: C-reactive protein, DM: diabetes mellitus, $\mathrm{Hb}$ : hemoglobin, HDL: high density lipoprotein, HT: hypertension, LDL: low density lipoprotein, NLR: neutrophil-to-lymphocyte ratio, PLR: platelet-to-lymphocyte ratio, MPV: mean platelet volume, Total Chol: total cholesterol, SD: standard deviation, WBC: white blood cell.

\begin{tabular}{|c|c|c|c|c|}
\hline & $\begin{array}{r}\begin{array}{r}\text { Control Group } \\
(\mathrm{n}=\mathbf{1 0 0})\end{array} \\
\end{array}$ & $\begin{array}{r}\begin{array}{r}\text { Patient Group } \\
(n=100)\end{array} \\
\end{array}$ & $\mathrm{X}^{2}$ value & p values \\
\hline Male, n(\%) & $45(45 \%)$ & $44(44 \%)$ & 0,01 & 0,923 \\
\hline HT Presence, n(\%) & $74(74 \%)$ & $81(81 \%)$ & 2,76 & 0,096 \\
\hline DM Presence, n(\%) & $36(36 \%)$ & $32(32 \%)$ & 1,21 & 0,271 \\
\hline Smoking, $\mathrm{n}(\%)$ & $45(45 \%)$ & $37(37 \%)$ & 3,35 & 0,067 \\
\hline Statin Use,n(\%) & $52(52 \%)$ & $49(49 \%)$ & 0,54 & 0,462 \\
\hline $\begin{array}{l}\text { Age (mean } \pm \text { SD) } \\
(\text { min-max })\end{array}$ & $\begin{array}{r}77,09 \pm 6,70 \\
(61-92)\end{array}$ & $\begin{array}{r}77,35 \pm 9,56 \\
(34-98)\end{array}$ & & 0,249 \\
\hline $\begin{array}{l}\mathrm{BMI}\left(\mathrm{kg} / \mathrm{m}^{2}\right)(\operatorname{mean} \pm \mathrm{SD}) \\
(\min -\max )\end{array}$ & $\begin{array}{r}26,39 \pm 3,26 \\
(21-35)\end{array}$ & $\begin{array}{r}25,86 \pm 4,03 \\
(17-35) \\
\end{array}$ & & 0,183 \\
\hline $\begin{array}{l}\mathrm{HDL}(\mathrm{mg} / \mathrm{dL})(\operatorname{mean} \pm \mathrm{SD}) \\
(\min -\mathrm{max})\end{array}$ & $\begin{array}{r}52,81 \pm 28,96 \\
(35-92) \\
\end{array}$ & $\begin{array}{r}45,93 \pm 15,61 \\
(28-75) \\
\end{array}$ & & 0,08 \\
\hline $\begin{array}{l}\mathrm{LDL}(\mathrm{mg} / \mathrm{dL})(\operatorname{mean} \pm \mathrm{SD}) \\
(\min -\mathrm{max})\end{array}$ & $\begin{array}{r}108,13 \pm 7,81 \\
(75-142) \\
\end{array}$ & $\begin{array}{r}106 \pm 7,46 \\
(77-152) \\
\end{array}$ & & 0,581 \\
\hline $\begin{array}{l}\text { Total Chol }(\mathrm{mg} / \mathrm{dL})(\operatorname{mean} \pm \mathrm{SD}) \\
(\min -\mathrm{max})\end{array}$ & $\begin{array}{r}179,45 \pm 37,51 \\
(129-267) \\
\end{array}$ & $\begin{array}{r}175,02 \pm 49,13 \\
(38-328) \\
\end{array}$ & & 0,587 \\
\hline $\begin{array}{l}\text { Creatine }(\text { mgr/dL) }(\text { mean } \pm \text { SD }) \\
(\min -m a x)\end{array}$ & $\begin{array}{r}0,80 \pm 0,12 \\
(0,56-1,2) \\
\end{array}$ & $\begin{array}{r}0,78 \pm 0,12 \\
(0,56-1,2) \\
\end{array}$ & & 0,117 \\
\hline $\begin{array}{l}\mathrm{Hb}(\mathrm{g} / \mathrm{dL})(\operatorname{mean} \pm \mathrm{SD}) \\
(\text { min-max })\end{array}$ & $\begin{array}{r}14,32 \pm 1,28 \\
(10,2-17,7) \\
\end{array}$ & $\begin{array}{r}14,18 \pm 1,89 \\
(7,8-19) \\
\end{array}$ & & 0,592 \\
\hline $\begin{array}{l}\text { Glucose }(\mathrm{mg} / \mathrm{dL})(\operatorname{mean} \pm \mathrm{SD}) \\
(\min -\mathrm{max})\end{array}$ & $\begin{array}{r}123,42 \pm 42,59 \\
(66-248) \\
\end{array}$ & $\begin{array}{r}125,53 \pm 26,95 \\
(67-212) \\
\end{array}$ & & 0,36 \\
\hline
\end{tabular}




\begin{tabular}{|c|c|c|c|}
\hline $\begin{array}{l}\text { MPV(fL) }(\text { mean } \pm \text { SD) } \\
(\min -\max )\end{array}$ & $\begin{array}{r}8,19 \pm 0,86 \\
(7,1-10,5) \\
\end{array}$ & $\begin{array}{r}9,01 \pm 1,02 \\
(6,8-10,9) \\
\end{array}$ & 0,11 \\
\hline $\begin{array}{l}\mathrm{CRP}(\mathrm{mg} / \mathrm{dl})(\operatorname{mean} \pm \mathrm{SD}) \\
(\min -\max )\end{array}$ & $\begin{array}{r}5,38 \pm 2,46 \\
(1,1-10,1)\end{array}$ & $\begin{array}{r}14,19 \pm 8,52 \\
(2,6-81,4)\end{array}$ & 0,001 \\
\hline $\begin{array}{l}\text { Platelet } \times 10^{3} / \mathrm{L}(\text { mean } \pm \mathrm{SD}) \\
(\text { min-max })\end{array}$ & $\begin{array}{r}207,52 \pm 41,63 \\
(112-413)\end{array}$ & $\begin{array}{r}276,78 \pm 74,90 \\
(20-465)\end{array}$ & 0,001 \\
\hline $\begin{array}{l}\text { Monocyte } \times 10^{9} / \mu \mathrm{l}(\text { mean } \pm \text { SD }) \\
(\min -m a x)\end{array}$ & $\begin{array}{r}540,44 \pm 94,10 \\
(100-1580) \\
\end{array}$ & $\begin{array}{r}608,03 \pm 260,54 \\
(220-2200) \\
\end{array}$ & 0,07 \\
\hline $\begin{array}{l}\text { Lymphocyte } \times 10^{9} / \mu \mathrm{I}(\text { mean } \pm \text { SD }) \\
(\text { min-max })\end{array}$ & $\begin{array}{r}1487,26 \pm 510,08 \\
(600-2900) \\
\end{array}$ & $\begin{array}{r}1270,69 \pm 708,29 \\
(100-4900) \\
\end{array}$ & 0,08 \\
\hline Neutrophil $\times 10^{9} / \mu \mathrm{l}($ mean \pm SD $)$ & $\begin{array}{r}7647,06 \pm 1275,05 \\
(2600-8600) \\
\end{array}$ & $\begin{array}{r}8420,04 \pm 3574,70 \\
(1090-22800) \\
\end{array}$ & 0,07 \\
\hline $\begin{array}{l}\mathrm{WBC} \times 10^{9} / \mu \mathrm{l}(\operatorname{mean} \pm \mathrm{SD}) \\
(\min -\mathrm{max})\end{array}$ & $\begin{array}{r}8937,26 \pm 1935,20 \\
(600-12200) \\
\end{array}$ & $\begin{array}{r}9670,82 \pm 3712,09 \\
(1400-25000) \\
\end{array}$ & 0,09 \\
\hline $\begin{array}{l}\text { NLR } \\
(\text { mean } \pm \text { SD) }\end{array}$ & $5,74 \pm 0,87$ & $6,42 \pm 0,78$ & 0,06 \\
\hline $\begin{array}{l}\text { PLR } \\
(\text { mean } \pm \text { SD })\end{array}$ & $217 \pm 14$ & $260 \pm 16$ & 0,04 \\
\hline
\end{tabular}

The determination of factors related to development of CSX; age, gender, presence of diabetes and hypertension, cigarette use, HDL, LDL, total cholesterol, hemoglobin, CRP, NLR and PLR levels were received as independent variables. Application of multivariate analyses on these parameters showed that CRP and PLR values were statistically significant independent variables for the prediction of CSX.

According to comparison of the hematological indices, mean value of the PLR in study population was higher than control group ( $260 \pm 16$ vs $217 \pm 14$, respectively; $p=0.04$ ) (Figure-1) whereas the other hematological parameters did not differ between groups significantly.

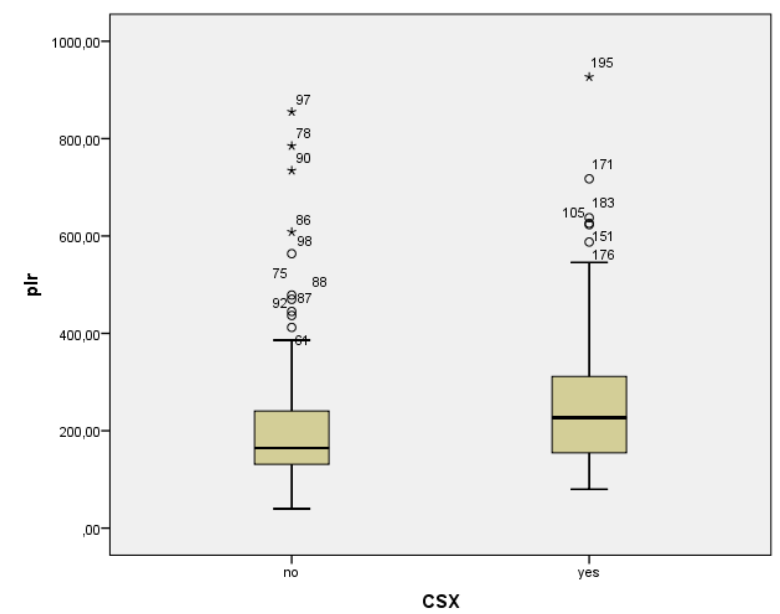

Figure-1: Comparison of PLR values between patients with CSX and control group

After that we used ROC analysis for determining the optimum cut-off PLR value for predicting CSX. The area under the curve (AUC) value was calculated as 0.972 (95\% confidence interval 0.950.98). The cut-off PLR value was observed as
242,48 with a sensitivity of $92.4 \%$ and specificity of 81.8 (Figure-2)

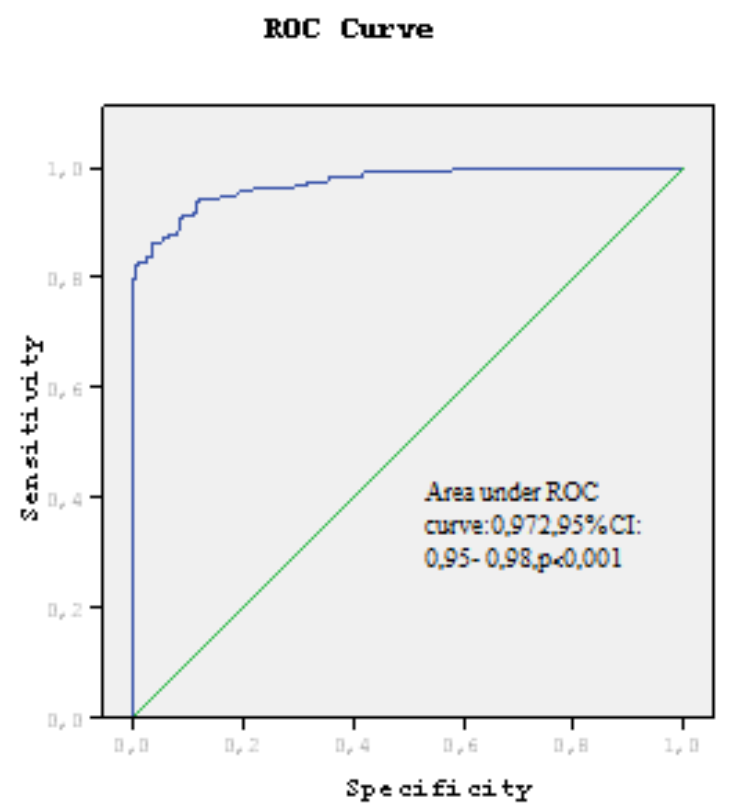

Figure-2: ROC analysis for determining the optimum cut-off PLR value for predicting CSX

\section{DISCUSSION}

The aim of this study is to evaluate the association between PLR, myocardial circulation, endothelial dysfunction and inflammation in CSX ${ }^{2}$. 
Between $10 \%$ and $30 \%$ of patients who have typical symptoms of angina pectoris, are noticed to have "normal" or "near normal" epicardial coronary arteries via diagnostic coronary angiography. Of these patients, those who suffer from predominantly effort-induced chest pain and transient myocardial perfusion abnormalities or ST-segment depression, or both, suggestive of myocardial ischemia during spontaneous or provoked angina are considered to be diagnosed as cardiac syndrome $\mathrm{X}$ (CSX). However, patients with left ventricular hypertrophy, coronary artery spasm and cardiomyopathy are usually excluded to have this syndrome.

CSX, which doesn't increase the risk of death alone, often causes a substantial cost burden to the health care system and severely impairs quality of life.

CSX is a heterogeneous syndrome that is considered to have a large number of possible causal cardiac and noncardiac mechanisms. Endothelial dysfunction of the coronary microcirculation becomes prominent among them.

The amount by which coronary flow increases in response to maximal arteriolar dilatation represents what is known as "coronary blood flow reserve" and reflects mainly the vasodilator capacity of the coronary microcirculation. An increase in coronary artery resistance or a reduction in this reserve or both, could exchange the balance between myocardial metabolic demand and coronary blood flow supply. A reasonable pathogenic mechanism in CSX is myocardial ischemia resulting from coronary microcirculation abnormalities ("microvascular angina"). Unfortunately, the causes of microvascular dysfunction in CSX have not been exactly elicited as yet and could be multiple.

Despite the pathophysiological mechanism of CSX have not yet been definetly understood, the subsequent microvascular ischemia and endothelial dysfunction may be the most mentioned pathophysiologic mechanisms for CSX, whose results may be the anginal-like chest pain in the patients with $\mathrm{CSX}^{3}$. Underlying pathophysiologic mechanisms of CSX are insulin resistance, abnormal autonomic control and microvascular spasm. The most convincing evidence is endothelial dysfunction. Endothelial dysfunction leads to reduced availability of nitric oxide, a decrease in the release of antiinflammatory and antithrombogenic factors, and abnormalities in the vasoconstruction/vasodilation balance ${ }^{4}$. The nitric oxide levels of these patiens decreses to basal levels and endotelin-1 levels of them increases ${ }^{5}$.
Most important, presence of endothelial dysfunction may be an indicator for a higher risk of future adverse outcomes ${ }^{6}$.

Research about the potential roles of inflammation as a pathogenic mechanism of CSX has amplified new ideas that could help to define more useful approachs for treating this difficult and heterogeneous syndrome. Inflammatory markers and noninvasive measurements of arterial wall structure and function may be used in determing CSX patients at risk of recurrent and severe anginal symptoms, and even those in whom the prognosis may not be as good as in others and who may benefit from aggressive interventions on endothelial dysfunction. Abnormal coronary arteries with atheromatous plaques and intimal thickening have been observed in intravascular ultrasonographic studies of patients with $\mathrm{CSX}^{7}$.

The platelet to lymphocyte ratio (PLR) has recently emerged as a potential inflammatory biomarker ${ }^{8}$. PLR is associated with worse outcome in various diseases ${ }^{9}$. The correlation between endothelial dysfunction and PLR is showned in previous studies. Kurtipek et $\mathrm{al}^{10}$ showed the association between endothelial dysfunction and PLR values in patients with pulmonary thromboembolism. Akbas et $\mathrm{al}^{11}$ showed same association in patients with diabetic nephropathy.

Endothelial dysfunction has also been associated with increased levels of CRP, a marker of chronic inflammation related to the development of vascular disease ${ }^{12}$. Higher levels of CRP have been shown to be related to more frequent and prolonged chest pain in patients with syndrome $\mathrm{X}$, along with an increased number of ischemic episodes as measured by 24 -hour Holter monitoring ${ }^{13}$. As CRP is a marker of inflammation that increases in response to injury, infection and pain ${ }^{14}$, the authors acknowledge that increased CRP levels related to ischemic events could be due to the more presence of chest pain alone. However, as CRP was related to ischemic episodes with or without the presence of chest pain, the authors argue that CRP is independently related to the pathogenesis of syndrome $\mathrm{X}$, and not simply a non-specific response to pain. The relationship between CRP levels and carotid artery stiffness has also been explored in relation to syndrome $\mathrm{X}^{15}$, suggesting that syndrome $\mathrm{X}$ patients had significantly higher CRP levels and carotid artery stiffness than controls. The authors suggest that there maybe a causal link between inflammation and the development of endothelial dysfunction, which in turn may be related to the presence of subclinical atherosclerotic plaque. 
According to the results of our study, it may be suggested that, despite of the normal coronary epicardial blood flow, subclinical inflammation might cause to impairment of microvascular circulation as reported by Rencio Mayoral et al ${ }^{16}$ and Rinkevich et $\mathrm{al}^{17}$.

This is a retrospective study. For this reason, undoubtedly, prospective randomized further clinical studies, which will be conducted in larger patient population and will clearly show the relation of PRL and CSX, are needed. So, to our

\section{REFERENCES}

1. Outcome of patients with a final diagnosis of chest pain of undetermined origin admitted under the suspicion of acute coronary syndrome. Laurence Prina,Wyat Decker,Amy Weaver. Ann Emerg Med.2004;43:59-67

2. Cardiac syndrome X. Kaski J.C. and Russo G. Hosp Pract (Off Ed) 2000;35:75-6

3. Cardiac syndrome $\mathrm{X}$ and endothelial dysfunction. Hurst T, Olson TH, Olson LE. American Journal of Medicine. July 2006-Volume 119,Issue 7,560-6

4. Role of endothelial dysfunction in atherosclerosis. Davignon J, Ganz P. Circulation. 2004;109:27-32.

5. Biochemical parameters of endothelial dysfunction in CSX. Kolasinska-Kloch W, Lesniak W, Kiec-Wilk B. Scand J Clin Lab.2002;62(1):713

6. Long term follow-up of patients with endothelial dysfunction. Suwaidi JA, Hamasaki S, Higano S, Nishimura RA, Holmes DR, Lerman A. Circulation.2000 Mar 7;101(9):948-54

7. Evaluation of mean platelet volume in patients with cardiac syndrome X. Demirkol S, Balta S, Unlu M. Clinics.2012;67(9):1019-22

8. Association of PLR with severity of coronary artery disease. Akboga MK, Canpolat U, Yayla C. Angiology.2006 Jan;67(1):89-95

9. NLR and PLR ratio in patients with dipper versus non-dipper hypertension. Sunbul M, Gerin F, Durmus E, Kivrak T. Clin Exp Hypertens.2014;36(4):217-21

10. Endothelial dysfunction in patients with PTE. Kurtipek E, Büyükterzi Z, Büyükterzi M. Clin Respir J 2015 Apr 27. doi: 10.1111 opinion, our study may inspire further trials to investigate the mechanisms involved in the development of CSX and the possible role of inflammation and endothelial dysfunction in this syndrome. The PLR, which is easily calculated from routinely studied compete blood count and therefore requires no additional cost might be usefull for the evaluation of CSX based on the results of our study.

Consequently,we demonstrated the relationship between PLR values and CSX, which might be used for this evaluation.

11. Association of epicardial adipose tissue, NLR and PLR with diabetic nephropaty. Akbas EM, Demirtas L, Ozcicek A. Int J Clin Exp Med. 2014 Jul 15;7(7):1794-801

12. Ridker PM, Cushman M, Stampfer MJ, Tracy $\mathrm{RP}$, Hennekens $\mathrm{CH}$. Inflammation, aspirin, and the risk of cardiovascular disease in apparently healthy men. N Engl J Med 1997; 336: 973-9

13. Cosin-Sales J, Pizzi C, Brown S, Kaski JC. Creactive protein, clinical presentation, and ischemic activity in patients with chest pain and normal coronary angiograms. J Am Coll Cardiol 2003; 41: 146-7

14. Rosalki SB. C-reactive protein. Int J Clin Pract 2001; 55: 26-7

15. Arroyo-Espliguero R, Mollichelli N, Avanzas $P$ et al. Chronic inflammation and increased arterial stiffness in patients with cardiac syndrome $X$. Eur Heart J 2003; 24: 200-1

16. Recio-Mayoral A, Rımoldı OE, Camıc PG, Kask1 JC. Inflammation and microvascular dysfunction in cardiac syndrome $\mathrm{X}$ patients without conventional risk factors for coronary artery disease. JACC Cardiovasc Imaging 2013;6:660-7

17. Rınkevich D, Belcık T, Gupta NC, Cannard E, Alkayed NJ, Kaul S. Coronary autoregulation is abnormal in syndrome $\mathrm{X}$ : Insights using myocardial contrast echocardiography. J Am Soc Echocardiogr 2013;26:290-6 